ISSN : 2303-1514 | E-ISSN : 2598-5949

\title{
OPTIMIZING THE COACHING TO IMPROVE TEACHERS' DISCIPLINE IN TEACHING AT SMP NEGERI 2 KUBU BABUSSALAM ROKAN HILIR REGENCY
}

\section{Baharuddin}

SMP Negeri 2 Kubu Babussalam, Rokan Hilir, Indonesia

baharuddinkubu@gmail.com

\section{OPTIMALISASI PEMBINAAN UNTUK MENINGKATKAN DISIPLIN GURU DALAM MENGAJAR DI SMP NEGERI 2 KUBU BABUSSALAM KABUPATEN ROKAN HILIR}

\begin{tabular}{|c|c|}
\hline ARTICLE HISTORY & ABSTRACT \\
\hline $\begin{array}{l}\text { Submitted: } \\
01 \text { Oktober } 2020 \\
01^{\text {st }} \text { October } 2020\end{array}$ & $\begin{array}{l}\text { Abstract: This research was a school action research aiming to improve and enhance the } \\
\text { learning process at schools, especially in the teachers' discipline in teaching. The action was } \\
\text { optimizing the coaching to improve teachers' discipline in teaching. The subjects in this study } \\
\text { consisted of } 26 \text { teachers at SMP Negeri } 2 \text { Kubu Babussalam. This study was conducted in SMP } \\
\text { Negeri } 2 \text { Kubu during two cycles. An observation was conducted in cycle I before the treatment } \\
\text { and in cycle II, the observation was conducted after the treatment. Data in this study were } \\
\text { collected through observations and the coaching treatment. The results showed that the } \\
\text { optimization of coaching improved the teachers' discipline and performance in teaching. It } \\
\text { could be seen from the percentage of teachers' discipline after the reflection which was } 83 \% \text {. } \\
\text { This percentage increased from the initial data which was only } 58 \% \text {. The increase of teachers ' } \\
\text { activities could also be seen from the observation analysis of the teachers' activities which } \\
\text { obtained a percentage of } 85 \% \text {. This value increased from the initial data which was only } 65 \% \text {. } \\
\text { Therefore, it could be concluded that the application of coaching improved teachers' discipline } \\
\text { in teaching at SMP Negeri } 2 \text { Kubu Babussalam Rokan Hilir. }\end{array}$ \\
\hline
\end{tabular}

Keywords: Teachers' discipline in Teaching, Coaching

Accepted:

02 Januari 2021

$02^{\text {nd }}$ January 2021

Published:

22 Februari 2021

$22^{\text {nd }}$ February 2021
Abstrak: Penelitian ini merupakan penelitian tindakan sekolah yang bertujuan untuk meningkatkan serta memperbaiki proses pembelajaran disekolah terutama pada disiplin guru dalam mengajar. Tindakan yang dilakukan yaitu berupa optimalisasi pembinaan untuk meningkatkan disiplin guru dalam mengajar. Subjek dalam penelitian ini terdiri dari 26 orang guru SMP Negeri 2 Kubu Babussalam. Penelitian ini dilakukan di SMP Negeri 2 Kubu, dilakukan dalam dua siklus yaitu siklus I pengamatan sebelum diberi tindakan dan siklus II sesudah diberi tindakan. Instrumen penelitian ini berupa observasi, dan tindakan pembinaan.Hasil penelitian menunjukkan bahwa tindakan optimalisasi pembinaan terhadap guru dapat meningkatkan disiplin serta kinerja guru dalam mengajar hal tersebut dapat dilihat dari persentase disiplin guru setelah refleksi didapat sebesar $83 \%$ mengalami peningkatan dibandingkan dengan data awal hanya 58\%, peningkatan kegiatan guru juga dapat dilihat dari analisa observasi kegiatan guru didapat persentase sebesar $85 \%$ terjadi peningkatan dibandingkan dengan data awal hanya $65 \%$, oleh karena hal tersebut dapat disimpulkan bahwa penerapan pembinaan dapat meningkatkan disiplin guru dalam mengajar di SMP Negeri 2 Kubu Babussalam Rokan Hilir.

Kata Kunci: Disiplin guru dalam Mengajar, Pembinaan

\section{CITATION}

Baharuddin. (2021). Optimizing The Coaching To Improve Teachers' Discipline In Teaching At Smp Negeri 2 Kubu Babussalam Rokan Hilir Regency. Primary: Jurnal Pendidikan Guru Sekolah Dasar, 10 (1), 235 - 242. DOI: http://dx.doi.org/10.33578/jpfkip.v10i1.8227. 


\section{PENDAHULUAN}

Peranan guru dalam proses belajar mengajar dan hasil belajar siswa sangat penting, maka guru diharapkan mampu menciptakan lingkungan belajar yang efektif dan akan mampu mengelola kelas (Haryati, 2016). Guru adalah pendidik profesional dengan tugas utama mendidik dan mengevaluasi peserta didik, pada pendidikan anak usia dini jalur pendidikan formal, pendidikan dasar dan pendidikan menengah (Rohmah, 2020). Kinerja guru diukur dari kegiatan guru dalam menyusun rencana pembelajaran, melaksanakan pembelajaran yang bermutu, mengevaluasi hasil pembelajaran, serta melaksanakan program pengayaan/melakukan tindak lanjut (Jumriah, 2016). Sementara pegawai dunia pendidikan merupakan bagian dari tenaga kependidikan, yaitu anggota masyarakat yang mengabdikan diri dan diangkat untuk menunjang penyelenggaraan pendidikan. Kedisiplinan guru diartikan sebagai sikap mental yang mengandung kerelaan mematuhi semua ketentuan, peraturan dan norma yang berlaku dalam menunaikan tugas dan tangung jawab (Pangabean, 2004).

Tugas guru dalam peningkatan kedisplinan merupakan tugas penting untuk keberhasilan belajar siswa untuk mencapai tujuan (Rahman, 2014; Zanwir, 2009). Sikap kedisiplinan harus tertanam pada diri guru dan peserta didik supaya dalam proses belajarmengajar di sekolah dapat berjalan dengan lancer, serta mampu mencapai kompetensi yang diinginkan oleh sekolah (Azmi, 2019). Kedisiplinan guru dan pegawai adalah sikap penuh kerelaan dalam mematuhi semua aturan dan norma yang ada dalam menjalankan tugasnya sebagai bentuk tanggung jawabnya terhadap pendidikan anak didiknya (Kurniaman, \& Noviana, 2017). Sejalan dengan pendapat (Jumriah, dkk, 2016) disiplin merupakan hal yang sangat penting, sebab dengan kedisiplinan dapat diketahui seberapa besar peraturan-peraturan dapat ditaati oleh guru. Dengan kedisiplinan di dalam mengajar guru, proses pembelajaran akan terlaksana secara efektif dan efesien.Karena bagaimana pun seorang guru atau tenaga kependidikan (pegawai), merupakan cermin bagi anak didiknya dalam sikap atau teladan, dan sikap disiplin guru dan tenaga kependidikan (pegawai) akan memberikan warna terhadap hasil pendidikan yang jauh lebih baik (Ali, 2014).

Menurut Anoraga (2001) disiplin adalah suatu sikap, perbuatan untuk selalu mentaati tata tertib. Pada pengertian disiplin juga tersimpul dua faktor yang penting, yaitu faktor waktu dan kegiatan atau perbuatan.Keteladanan guru dapat dilihat dari prilaku guru sehari-hari baik didalam sekolah maupun diluar sekolah. Selain keteladanan guru, kedisiplinan guru juga menjadi salah satu hal penting yang harus dimiliki oleh guru sebagai seorang pengajar dan pendidik (Altar, 2014). Berdasarkan pengamatan sementara di SMP Negeri 2 Kubu Babussalam Kabupaten Rokan Hilir, ditemukan fenomena antara lain, masih dijumpai guru yang terlambat datang ke sekolah dan pulang lebih awal. Masih kurangnya Disiplin guru dalam mengajar di kelas, hal ini ini terlihat dari adanya sebagian siswa yang gaduh di ruang kelas. Adanya sebagian guru guru yang sering terlambat masuk kelas. Adanya sebagian guru yang kurang persiapanya dalam mengajar seperti tidak melengkapi RPP ataupun media pembelajaran lainnya. Manfaat penelitian ini adalah setelah diterapkannya berbagai tindakan diharapkan dapat meningkatkan disiplin guru dalam mengajar di SMP Negeri 2 Kubu Babussalam.

\section{KAJIAN TEORI}

Disiplin adalah kesadaran dan kesediaan seseorang mentaati semua peraturan perusahaan dan norma-norma sosial yang berlaku. Adapun arti kesadaran adalah sikap seseorang yang secara sukarela menaati semua peraturan dan sadar akan tugas dan tanggung 
jawabnya. Sedangkan arti kesediaan adalah suatu sikap, tingkah laku, dan perbuatan seseorang yang sesuai dengan peraturan perusahaan baik yang tertulis maupun tidak (Hasibuan ,1997). Disiplin kerja dapat diartikan sebagai pelaksanaan manajemen untuk memperteguh pedoman-pedoman organisasi (Mangkunegara, 2000).

Sastrohadiwiryo (2005) mengatakan bahwa disiplin kerja adalah suatu sikap menghormati, menghargai, patuh, dan taat terhadap peraturan-peraturan yang berlaku, baik yang tertulis maupun yang tidak tertulis serta sanggup menjalankannya dan tidak mengelak untuk menerima sangsi-sangsinya apabila ia melanggar tugas dan wewenang yang diberikan kepadanya.

Sinungan (2003) mengatakan bahwa disiplin adalah suatu sikap mental yang tercermin dalam perbuatan atau tingkah laku perorangan, kelompok atau masyarakat berupa ketaatan (obedience) terhadap peraturanperaturan atau ketentuan yang ditetapkan pemerintah atau etika, norma dan kaedah yang berlaku dalam dalam masyarakat untuk tujuan tertentu.

Berdasarkan berbagai definisi mengenai disiplin diatas dapat disimpulkan bahwa disiplin kerja merupakan cerminan sejauhmana besarnya rasa tanggung jawab dan pengabdian seseorang terhadap tugas dan tanggung jawabnya. Kedisiplinan guru merupakan masalah kehidupan dan selalu menjadi komponen yang penting dalam suatu organisasi. Tujuan organisasi baru akan tercapai apabila program-program kerja yang telah ditentukan telah ditetapkan dapat dilaksanakan dengan efektif dan efisien.

Adapun yang dimaksud dengan pembinaan guru atau pengembangan guru menurut Iswanto (2014), "pembinaan guru adalah usaha yang dilakukan untuk memajukan dan meningkatkan mutu serta efisiensi kerja seluruh tenaga personalia yang berbeda dalam lingkungan sekolah baik tenaga edukatif maupun administratif." Pendapat lain disampaikan oleh Pupah Mustika (2017), pembinaan guru diartikan sebagai“ serangkaian usaha bantuan kepada guru, terutama bantuan yang berwujud layanan profesional yang dilakukan oleh kepala sekolah, penilik, dan pengawas sekolah serta pembina lainnya untuk meningkatkan proses dan hasil belajar."

Indikator pelaksanaan pembinaan adalah 1) pembinaan keterampilan guru dalam mengajar melalui kelompok kerja guru (KKG), 2) pembinaan keterampilan guru dalam mengajar melalui supervisi, 3) pembinaan keterampilan guru dalam mengajar melalui seminar workshop, 4) pembinaan keterampilan guru dalam mengajar melalui pendidikan dan pelatihan (Aminah dkk, 2012).

Berdasarkan pendapat di atas dapat disimpulkan bahwa pembinaan guru adalah serangkaian usaha yang dilakukan oleh kepala sekolah, penilik, pengawas, dan pembina lainnya terhadap guru dengan tujuan untuk memajukan dan meningkatkan mutu kerja tenaga pendidik dalam lingkungan sekolah sehingga proses dan hasil belajar menjadi meningkat.

\section{METODE PENELITIAN}

Jenis penelitian ini adalah Penelitian Tindakan Sekolah (PTS) berlokasi di SMP Negeri 2 Kubu Babussalam Kabupaten Rokan Hilir, yang ditujukan pada guru-guru. penelitian ini bertujuan untuk meningkatkan disiplin guru dalam mengajar di SMP Negeri 2 Kubu Babussalam, subjek dalam penelitian ini terdiri dari 26 orang.

\section{Prosedur Penelitian}

Penelitian ini terdiri dari 2 siklus, adapun setiap siklus dilakukan dalam 2 kali pertemuan. Adapun tahapan-tahapan yang dilalui dalam penelitian tindakan kelas,

1. Perencanaan/persiapan tindakan

2. Pelaksanaan tindakan

3. Observasi

4. Refleksi

a. Perencanaan/persiapan 
Dalam tahap perencanaan atau persiapan tindakan ini, langkah-langkah yang dilakukan adalah sebagai berikut:

1. Menyusun tujuan operasional

2. Membuat lembar kerja dan menyusun lembar kerja guru untuk mengetahui Disiplin guru dalam kehadiran mengajar .

3. Menyiapkan format pengamatan proses pembelajaran yang terdiri dari situasi kegiatan belajar mengajar, keaktifan guru dalam pembelajaran.

4. Menyusun lembar observasi pengukuran Disiplin guru dalam mengajar .

b. Implementasi Tindakan

1) Peneliti memberikan pembinaan keterampilan guru dalam mengajar melalui kelompok kerja.

2) Peneliti memberikan pembinaan keterampilan guru dalam mengajar melalui supervisi

3) Peneliti memberikan pembinaan keterampilan guru dalam mengajar melalui seminar workshop

4) Peneliti memberikan pembinaan keterampilan guru dalam mengajar melalui pendidikan dan pelatihan.

\section{c. Observasi}

Pengamatan atau observasi yang dilakukan dalam penelitian ini dilakukan oleh teman sejawat yang telah bersedia menjadi observer dalam penelitian ini dengan menggunakan format pengamatan yang telah disediakan. Aspek-aspek yang diamati antara lain kegiatan Pembinaan dan Disiplin guru dalam mengajar .

\section{d. Refleksi}

Setelah perbaikan pembelajaran dilaksanakan peneliti dan observer melakukan kerjasama dan menganalisa hasil dari proses pembelajaran yang dilaksanakan, sehingga diketahui keberhasilan dan kelemahan pembelajaran yang telah dilaksanakan. Hasil dari analisa data tersebut dijadikan sebagai landasan untuk siklus berikutnya, sehingga antara siklus I dan siklus II ada kesinambungan dan diharapkan kelemahan pada siklus yang pertama dapat dijadikan sebagai dasar perbaikan pada siklus yang berikutnya.

\section{Teknik Analisis Data}

Adapun tekhnik analisa data dalam penelitian ini adalah menggunakan rumus persentase (Anas Sudijono, 2004) sebagai berikut:

$$
p=\frac{\mathrm{f}}{\mathrm{n}} \times 100 \%
$$

Keterangan:

$\mathrm{f}=$ Frekuensi yang sedang dicari persentasenya

$\mathrm{n}=$ Number of Cases (jumlah frekuensi/banyaknya individu)

$\mathrm{P}=$ Angka persentase

$100 \%=$ Bilangan Tetap

Tabel 1. Klasifikasi Pengukuran Observasi Disiplin guru dalam Mengajar

\begin{tabular}{ccc}
\hline No & Klasifikasi & Persentase (\%) \\
\hline 1 & Baik & $67-100$ \\
2 & Cukup Baik & $34-66$ \\
3 & Kurang Baik & $0-33$ \\
\hline
\end{tabular}

\section{HASIL DAN PEMBAHASAN}

\section{a. Observasi}

Analisa data observasi pembinaan terhadap guru dilakukan sebanyak 2 siklus, siklus I didapat hasil dengan rata-rata sebesar $65 \%$, Artinya masih membutuhkan pengulangan pada siklus berikutnya karena memang belum begitu memuaskan. Kemudian dilakukan refleksi yaitu pada siklus ke II didapat hasil dengan rata-rata $85 \%$. Berikut adalah data hasil observasi terhadap guru 
sikulus II setelah dilakukan refleksi pembinaan

disiplin terhadap guru:

Tabel 2. Aspek Kegiatan Pembinaan Pada Siklus II

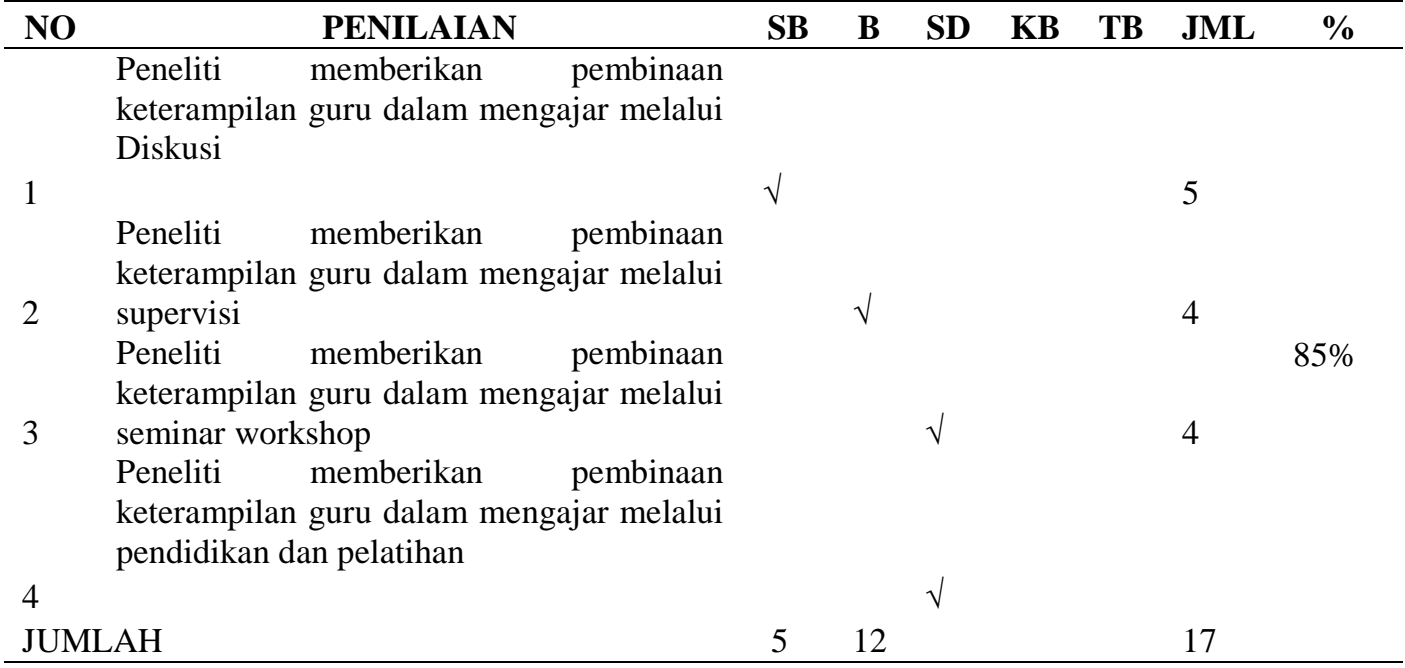

Dari tabel di atas dapat dilihat bahwa setelah dilakukan refleksi terhadap guru melalui beberapa tindakan pembinaan, persentase observasi aspek kegiatan guru mengajar mengalami peningkatan yang cukup signifikan dibandingkan dengan data awal hanya $65 \%$ kemudian setelah dilakukan refleksi hasil analisis observasi kegiatan guru meningkat dengan jumlah persentase sebesar $85 \%$.

\section{b. Penilaian disiplin guru}

Data analisis disiplin guru dalam mengajar di SMP Negeri 2 Kubu Babussalam dilakukan dengan 2 siklus. pada siklus I data disiplin guru dalam mengajar hanya sebesar $58 \%$, kemudian dilakukan refleksi berupa tindakan pembinaan pada siklus ke II, untuk lebih jelanya dapat dilihat pada table berikut:

Tabel 3. Disiplin guru dalam Mengajar Pada Siklus II

\begin{tabular}{rlcccccc}
\hline \multicolumn{1}{c}{ NO } & \multicolumn{1}{c}{ Nama Guru } & $\mathbf{1}$ & $\mathbf{2}$ & $\mathbf{3}$ & Jumlah & Persentase & keterangan \\
\cline { 2 - 5 } 1 & GUSTIANA & 1 & 1 & 1 & 3 & 100 & baik \\
2 & NOVITA ASNUR & 0 & 1 & 1 & 2 & 67 & baik \\
3 & KASMI DELITA & 1 & 1 & 1 & 3 & 100 & baik \\
4 & ERMILAYANI & 0 & 1 & 1 & 2 & 67 & baik \\
5 & FENNI WIDYASTUTI & 1 & 1 & 1 & 3 & 100 & baik \\
6 & SYAFRITAMURNI & 0 & 1 & 1 & 2 & 67 & baik \\
7 & MASUKARDI & 1 & 1 & 1 & 3 & 100 & baik \\
8 & YUSNADEWI & 1 & 1 & 1 & 3 & 100 & baik \\
9 & LISA HANDAYANI & 1 & 1 & 1 & 3 & 100 & baik \\
10 & ENUR SUMINAR & 0 & 1 & 1 & 2 & 67 & baik \\
11 & HASMIYATI & 1 & 1 & 1 & 3 & 100 & baik \\
12 & KOMARIYATIN & 0 & 1 & 1 & 2 & 67 & baik
\end{tabular}




\begin{tabular}{llcc}
13 & AZMI & 1 & 1 \\
14 & ROFLI & 0 & 1 \\
15 & ZURAIDA & 1 & 1 \\
16 & HOTMAULI & 1 & 1 \\
17 & PENDI & 1 & 1 \\
18 & NURZAZILI & 1 & 0 \\
19 & ASROF & 1 & 1 \\
20 & M FAUZI & 1 & 1 \\
21 & MARIANA & 0 & 1 \\
22 & SITI ROHANI & 1 & 1 \\
23 & NURASIAH & 1 & 1 \\
24 & SYAMSURI & 1 & 1 \\
25 & KUSRINI & 1 & 0 \\
26 & DESTI ASTUTI & 1 & 1 \\
& jumlah & 19 & 24 \\
& rata-rata & 73.1 & 92.3 \\
\hline
\end{tabular}

\begin{tabular}{cccc}
1 & 3 & 100 & baik \\
1 & 2 & 67 & baik \\
1 & 3 & 100 & baik \\
1 & 3 & 100 & baik \\
1 & 3 & 100 & baik \\
0 & 1 & 33 & cukup baik \\
0 & 2 & 67 & baik \\
1 & 3 & 100 & baik \\
1 & 2 & 67 & baik \\
1 & 3 & 100 & baik \\
1 & 3 & 100 & baik \\
1 & 3 & 100 & baik \\
0 & 1 & 33 & cukup baik \\
0 & 2 & 67 & baik \\
22 & 65 & 2167 & \\
84.6 & 250 & 83 & baik \\
\hline
\end{tabular}

Dari data di atas dapat disimpulkan bahwa setelah dilakukan refleksi pembinaan terhadap guru diperoleh persentase dari aspek Disiplin guru dalam mengajar dengan rata-rata persentase sebesar $83 \%$ atau dengan kategori sangat baik. Dibandingkan dengan data awal hanya 58\% dengan kategori cukup.
Data perbandingan penilaian disiplin guru dalam mengajar di SMP Negeri 2 Kubu Babussalam didapat melalui dua siklus, penilaian perbandingannya dapat dilihat pada tabel berikut:

Tabel 4. Perbandingan Disiplin guru dalam Mengajarpada Siklus I dan II

\begin{tabular}{ccc}
\hline KET & PERSENTASE KLASIKAL & KATEGORI \\
\hline SIKLUS I & 58 & Cukup baik \\
SIKLUS II & 83 & Sangat Baik \\
\hline
\end{tabular}

Tabel diatas merupakan perbandingan penilaian disiplin guru dalam mengajar, pada aspek disiplin guru dalam mengajar didapatkan pada siklus I sebesar 58\% dengan kategori baik dan pada siklus II meningkat menjadi $83 \%$ dengan kategori sangat baik. Berdasarkan dari data diatas dapat disimpulkan bahwa persentase disiplin guru dalam mengajar terjadi peningkatan yang signifikan dapat dikatakan penerapan pembinaan yang dilakukan kepada guru sangat efektif diterapkan.

\section{Pembahasan}

Penelitian ini merupakan penelitian tindakan sekolah yang bertujuan untuk meningkatkan serta memperbaiki proses pembelajaran disekolah terutama pada disiplin guru dalam mengajar. Tindakan yang dilakukan yaitu berupa optimalisasi pembinaan untuk meningkatkan disiplin guru dalam mengajar di SMP Negeri 2 Kubu Babussalam. Subjek dalam penelitian ini terdiri dari 26 orang guru SMP Negeri 2 Kubu Babussalam. Penelitian ini dilakukan dalam dua siklus yaitu siklus I pengamatan sebelum diberi tindakan dan siklus II sesudah diberi tindakan. 
Instrumen penelitian ini berupa observasi, dan tindakan pembinaan.

Berdasarkan dari hasil penelitian setelah dilakukan refleksi berupa tindakan pembinaan dapat dilihat bahwa disiplin guru dalam mengajar mengalami peningkatan yang cukup baik dengan persentase sebesar 83\% dengan kategori sangat baik, begitu juga dengan kegiatan guru juga mengalami peningkatan dengan persentase sebesar $85 \%$ dengan kategori sangat baik. Melihat terjadinya peningkatan yang signifikan tersebut dapat disimpulkan bahwa optimalisasi pembinaan terhadap disiplin guru sangat efektif dilakukan terhadap guru di SMP Negeri 2 Kubu Babussalam. Hal tersebut sejalan dengan penelitian Rohmah (2020) mengatakan bahwa penerapan pembinaan terhadap kinerja guru dapat membuat guru menjadi lebih disiplin dalam segi waktu dan memperhatikan aspek-aspek yang berhubungan dengan pengajaran yang baik sehingga dapat meningkatkan proses pembelajaran dengan baik.. Hal itu juga sejalan dengan penelitian Marlina (2016) mengatakan bahwa pembinaan terhadap guru dapat memberdayakan akuntabilitas guru serta meningkatkan mutu proses dan hasil belajar.

Pembinaan sangat berpengaruh terhadap meningkatnya disiplin guru dalam mengajar, sebagaimana hal nya yang dikatakan oleh Baharun (2017) mengatakan bahwa pembinaan sangat penting diberikan terhadap guru, karena pembinaan memiliki tujuan untuk meningkatkan profesionalitas guru di lembaga pendidikan. Guru yang mengajar dengan profesional dan efektif akan menghasilkan perilaku belajar yang efektif dan akan menghasilkan hasil belajar yang baik dan bermutu (Hasibuan, 2007).

\section{SIMPULAN DAN REKOMENDASI}

Dari uraian pengolahan data dan pembahasan didapatkan kesimpulan bahwa Disiplin guru dalam mengajar setelah diberikan tindakan pembinaan mengalami peningkatan didapatkan pada siklus I sebesar
58\% dengan kategori baik dan pada siklus II meningkat menjadi $83 \%$ dengan kategori baik. Kemudian observasi pada aspek kegiatan pembinaan juga mengalami peningkatan yang pada data awal hanya $65 \%$ setelah diberi tindakan meningkat menjadi $85 \%$ dengan kategori sangat baik. Artinya bahwa Kegiatan Pembinaan dapat Meningkatkan Disiplin guru dalam mengajar di SMP Negeri 2 Kubu Babussalam Kabupaten Rokan Hilir dikatakan berhasil.

\section{Rekomendasi}

Berdasarkan temuan penelitian di atas, serta mengingat bahwa Optimalisasi Pembinaan Untuk Meningkatkan Disiplin guru dalam Mengajar di SMP Negeri 2 Kubu Babussalam Kabupaten Rokan Hilir, maka disarankan perlunya peningkatan kegiatan tersebut di masa yang akan datang. Sehubungan dengan itu disarankan kepada berbagai pihak untuk menindaklanjuti hasil penelitian ini.

\section{DAFTAR PUSTAKA}

Altar, H. (2014). Peningkatan Disiplin Kehadiran Mengajar Guru di Kelas Melalui Keteladanan Kepala Sekolah di SMP Negeri 5 Sengkang Kabupaten Wajo. Jurnal Letera Pendidikan, 17, (1), 92-109.

Aminah. (2012). Pembinaan kompetensi professional guru oleh kepala sekolah SMP Negeri 2 Kota Sigli, jurnal administrasi pendidikan, 1 (1), 1-13.

Azmi. (2019). Meningkatkan Disiplin Guru dalam Kehadiran ke Sekolah dan Mengajar di Kelas Melalui Penerapan "Reward and Punishment". Jurnal PAJAR (Pendidikan dan Pengajaran), 3 (3), 550-559. DOI: http://dx.doi.org/10.33578/pjr.v3i3.7117

Anas, S. (2004). Pengantar Statistik Pendidikan. Jakarta: Raja Grafindo

Anoraga, P. (2001). Psikologi Kerja. Jakarta: Rineka Cipta. 
Ali, M. (2014). Guru Dalam Proses Belajar Mengajar. Bandung: Sinar Baru Algensindo.

Arikunto, S. (2014). Penelitian Tindakan Kelas. Jakarta: Rineka Cipta.

Baharun, H. (2017). Peningkatan kompetensi guru melalui system kepemimpinan kepala madrasah. Jurnal ilmu tarbiyah, $6(1)$.

Hasibuan, M. (1997). Manajemen Sumber Daya Manusia. Jakarta: Gunung Agung.

Hasibuan. (2007). Manajemen sumber daya manusia. Jakarta: Bumi Aksara.

Haryati, L. (2016). Upaya Meningkatkan Disiplin Guru dalam Kehadiran Mengajar di Kelas Melalui Penerapan "Reward and Punishment". Jurnal Media Didaktika, 2 (2), 191-200.

Iswanto, M. (2014). Pengaruh model pembinaan guru dalam meningkatkan kinerja guru SMK Negeri 4 Bojonegoro. jurnal manajemen dan administrasi public, 2(1), 88-102.

Jumriah, dkk. (2016). Disiplin Kerja Guru Dalam Melaksanakan Tugas Pembelajaran Di Sekolah Menengah Kejuruan Negeri 1 Barru. Jurnal Office, 2 (1), 155-162.

Kurniaman, O., \& Noviana, E. (2017). Penerapan Kurikulum 2013 dalam Meningkatkan Keterampilan Sikap dan Pengetahuan. Prmary: Jurnal Pendidikan Guru Sekolah Dasar, 6 (2), 389-

396. DOI:10.33578/jpfkp.v6i2.4520.

Mustika, P. (2017). Pengaruh pelaksanaan kebijakan pembinaan guru terhadap disiplin kerja dalam mewujudkan mutu pelayanan pendidikan. jurnal pendidikan universitas garut, 11(1), 50-57.

Rahman, A. (2014). Peningkatan Disiplin Kerja Guru di Sekolah Dasar Yayasan Mutiara Gambut. Jurnal Administrasi Pendidikan, 2 (1), 1-831.
Sastrohadiwiryo. (2005). Manajemen Tenaga Kerja Indonesia. Bandung: Rosdakarya.

Sinungan, M. (2003). Produktivitas: apa dan Bagaimana. Jakarta: Bumi Aksara.

Mangkunegara, A. P. (2000). Manajemen Sumber Daya Manusia Perusahaan. Bandung: Rosdakarya.

Marlina, L. (2016). Kajian system pembinaan profesional guru IPA. jurnal edufisika, 1 (2), 25-32.

Panggabean, M. (2004). Manajemen sumber daya manusia. Jakarta: Ghalia Indonesia.

Rohmah. (2020). Evaluasi terhadap pembinaan kinerja guru. JolEM, 1 (2), 1-13.

Hasibuan, M. (2007). Manajemen sumber daya manusia. Jakarta: Bumi Aksara.

Zanwir. (2009). Upaya Menciptakan Sekolah yang Aman, Nyaman dan Efektif dalam Pembelajaran. Padang: Balai Pendidikan dan Kepelatihan Keagamaan Padang. 